\title{
Effect of using kefir in the formulation of traditional Tarhana
}

\author{
Ahmet Sukru DEMIRCI ${ }^{1}$, Ibrahim PALABIYIK ${ }^{1}$, Seymanur OZALP ${ }^{1}$, Goksel TIRPANCI SIVRI ${ }^{1 *}$
}

\begin{abstract}
Tarhana is known as a fermented cereal product made traditionally from wheat flour and yoghurt. As a novelty, kefir was used as substitute for yoghurt in tarhana production partially and completely to investigate the effects on fermentation activity, nutritional, sensory and rheological properties of tarhana. Addition of kefir increased the fermentation activity as raise in acidity values was observed compared to tarhana samples prepared with yoghurt. Regarding dry tarhana samples, the highest acidity degree, protein, ash and phenolic contents were detected in samples prepared with $100 \%$ kefir. Counts of LAB groups (M17 and MRS agar) of tarhana enriched with 100\% kefir was higher than that of other tarhana samples during the fermentation period. Moreover, kefir affected the scores of sensory properties of tarhana soups. Tarhana soups prepared with kefir gave the highest scores for mouth feel, odour and consistency attributes. Tarhana soup prepared with $50 \%$ yoghurt and kefir showed the lowest viscosity probably due to synergistic effect on starch hydrolysis by bacterial population from both ingredients. These results suggest that replacement of yogurt with kefir in the formulation of Tarhana may enhance some properties of the soup.
\end{abstract}

Keywords: Tarhana; kefir; rheological behavior; fermentation; sensorial property.

Practical Application: Using Kefir instead of yoghurt in the formulation of tarhana may provide a novel product.

\section{Introduction}

Traditional Turkish fermented cereal product called tarhana is mainly prepared by lactic acid and alcoholic fermentation of yoghurt, wheat flour, yeast, and a variety of vegetables and some spices mixture for 1-7 days. This fermented dough is also called wet tarhana. Acid is formed by lactic acid bacteria (LAB) and yeast during fermentation and leavening effect. The final product can be included in fermented foods known by acidic taste and yeast aroma (Ibanoglu et al., 1999a; Sengun et al., 2009). Tarhana can be used in diet of children and elderly people as it is a good source of minerals, vitamins and proteins (Daglioglu, 2000).

After fermentation, the dough mixture is dried and then ground to a particle size of $<1 \mathrm{~mm}$. Generally, soup is made from tarhana for consumption and has an acidic and sour taste with a strong yeasty flavour. Alternatively, dried tarhana is also locally consumed as a snack (Erbaş et al., 2006; Ibanoglu et al., 1995).

Nutritional and sensory properties of tarhana changed according to ingredients and their ratios in the recipe (Erbaş et al., 2005). Fermentation process increases the nutritional and functional properties, taste and flavor of tarhana dough. This can be due to the synergistic effect between the activity of yeast and fermentative LAB, present in Tarhana (Mensah, 1997). During fermentation, interaction of yeast and LAB can cause the occurrence of metabolites, which might result in pleasant tastes and flavors in foods (Mugula et al., 2003).

In previous studies, it has been reported that tarhana was enriched by lentil and chickpea (Türker \& Elgün, 1995), soybean
(Koca et al., 2002), whole wheat meal and bulgur (Toufeili et al., 1998), corn (Tarakçi et al., 2004), barley (Erkan et al., 2006) and whole wheat and chickpea flours (Kumral, 2015).

When mixed cultures are used, there may be a number of important advantages in terms of enhanced texture and flavor (Meignen et al., 2001), elongation of expiry date by the produced antimicrobial compounds (organic acids and bacteriocins) (Messens \& De Vuyst, 2002).

Kefir which is an acidifying and mildly alcoholic fermented milk originated from the Caucasian mountains, is accepted as a good example of a probiotic mixture of bacteria and yeast (Simova et al., 2002). Many microorganisms such as yeasts (Kluyveromyces, Candida, Torulopsis and Saccharomyces sp.), lactic acid bacteria (Lactobacillus, Lactococcus, Leuconostoc, Acetobacter and Streptococcus spp.) and occasionally acetic acid bacteria which share synbiotic relationships, have been isolated from kefir microflora (Simova et al., 2002). In the treatment of several illnesses like tuberculosis, cancer and gastrointestinal disorders caused by pathogenic microorganisms, this probiotic dairy drink is widely used in various parts of the world (Libudzsis \& Piatkiewicz, 1990). Kefir was also used in various fermented products like bread, cheese making and milk fermentation successfully. The use of kefir in replacement of yoghurt in the production of tarhana has not been investigated and it may improve fermentation, physico-chemical and sensory properties. 
In this study, it is aimed to determine chemical and microbiological changes of tarhana made with kefir used in the replacement of yoghurt completely and partially during a typical 4-day tarhana fermentation and to determine sensorial and rheological properties of these tarhana soups.

\section{Materials and methods}

\subsection{Materials}

Wheat flour, onions, yeast, yoghurt, pure tomato, red pepper, salt mixed in tarhana production were obtained from retailer in Tekirdağ, Turkey. The percent of crude protein in wheat flour was 11.45 . Full fat (3.1\%) set yoghurt having $\mathrm{pH}$ value of 3.9 and baker's yeast in active dry form were used. Kefir grains were obtained from the Faculty of Agriculture, Department of Food Engineering in Namık Kemal University, Turkey.

\subsection{Production of Tarhana}

Standard tarhana (Sample A) was obtained by the following ingredients according to Bilgiçli et al. (2006): wheat flour (1000 g), yoghurt $(500 \mathrm{~g})$, onion $(120 \mathrm{~g})$, tomato $(120 \mathrm{~g})$, red pepper $(120 \mathrm{~g})$, baker's yeast $(10 \mathrm{~g})$ and salt $(40 \mathrm{~g})$. In kefir enriched tarhana samples, yoghurt replaced with 50\% (Sample B) and $100 \%$ (Sample C) (w/w) kefir drink. The recipes used in the preparation of tarhana samples were given in Table 1.

To produce tarhana dough, tomato, onion and red pepper were smashed, blended and sieved $(1 \mathrm{~mm})$ followed by pasteurization at $65^{\circ} \mathrm{C}$ for $30 \mathrm{~min}$ and cooled to ambient temperature. Then yoghurt/kefir, yeast and wheat flour were added and the mixture was kneaded to obtain a dough. Dough fermentation took place at $30 \pm 1{ }^{\circ} \mathrm{C}$ for 7 days in an incubator. Sampling of this tarhana dough was done on day $0,1,3,5$ and 7 during the fermentation period to investigate chemical and microbiological changes. After fermentation, the tarhana was dried at room temperature and then ground and sieved to pass a $1 \mathrm{~mm}$ screen

\subsection{Kefir production}

Cow milk was heated to $80^{\circ} \mathrm{C}$ for $30 \mathrm{~min}$ in a water bath, before cooling to inoculation temperature. After pasteurization and cooling of milk, kefir grains (5\%) (w/w) were added and left to incubation for $24 \mathrm{~h}$ with stirring at $25^{\circ} \mathrm{C}$. When fermentation was completed, the grains were separated from the milk by filtering with a sterile sieve and kefir was cooled to approximately to $+4{ }^{\circ} \mathrm{C}$ and stored at this temperature for 7 days.

Table 1. Amounts of ingredients for tarhana samples.

\begin{tabular}{cc}
\hline Ingredients & Amount $(\mathrm{g})$ \\
\hline Flour & 1000 \\
Yoghurt/Kefir & $500^{\mathrm{a}, \mathrm{b}, \mathrm{c}}$ \\
Onion & 120 \\
Tomato puree & 120 \\
Red pepper & 120 \\
Yeast & 10 \\
Salt & 40 \\
\hline
\end{tabular}

${ }^{a}$ samples with $100 \%$ yoghurt content; ${ }^{b}$ samples with $50 \%$ yoghurt and $50 \%$ kefir content; 'samples with $100 \%$ kefir content.

\subsection{Microbiological analysis}

After homogenized with a stomacher, tarhana samples $(25 \mathrm{~g})$ were diluted and decimal dilutions were conducted in sterile physiological solution (225 g). Plating and incubation of microbial suspensions were conducted as the following: yeast and molds on potato dextrose agar (PDA), incubated at $25^{\circ} \mathrm{C}$ for $48 \mathrm{~h}$; total mesophilic count (TMC) on plate count agar (PCA), incubated at $30^{\circ} \mathrm{C}$ for $72 \mathrm{~h}$; coliforms on violet red bile agar (VRBA), incubated at $37^{\circ} \mathrm{C}$ for $24 \mathrm{~h}$; S. aureus on Baird Parker agar (BPA), incubated at $37^{\circ} \mathrm{C}$ for $24 \mathrm{~h}$; mesophilic rod and coccus LAB on MRS and M17 agar, respectiveley, incubated at $30^{\circ} \mathrm{C}$ for $48 \mathrm{~h}$. All media were purchased from Merck (Darmstadt, Germany). Counts were carried out in duplicate and the results were expressed as $\log _{10} \mathrm{cfu} / \mathrm{g}$.

\subsection{Chemical analysis}

The amounts of protein (method 46-12), ash (method 08-03) and moisture (method 44-12), of the tarhana samples were measured according to standard methods (American Association of Cereal Chemists, 1990). The Mohr method (Kirk \& Sawyer, 1991) was used to determine salt content of samples. The acidity degree (as lactic acid) was determined by the Tarhana Standard (TS 2282) of Turkish Standards Institute (Anonymous, 1981). $\mathrm{pH}$ was determined using a $\mathrm{pH}$ meter (Hanna Instruments 211) after mixing a $5 \mathrm{~g}$ sample with $100 \mathrm{ml}$ distilled water.

\subsection{Determination of total phenolic compounds}

Amounts of total phenolic compounds in the samples were determined according to Škerget et al. (2005) as mM gallic acid/g dry sample using UV spectroscopy (Shimadzu UV-1208), according to a colorimetric oxidation/reduction reaction. The Folin-Ciocalteu reagent was used as an oxidizing agent and extraction of the samples with pure methanol was conducted at $40^{\circ} \mathrm{C}$.

\subsection{Rheological analysis}

$20 \mathrm{~g}$ dry tarhana powder and $200 \mathrm{~mL}$ distilled water was mixed and simmered over medium heat with constant stirring for $15 \mathrm{~min}$. Rheological analysis of solutions were conducted using a controlled stress Discovery Hybrid Rheometer-2 (TA Instruments New Castle, DE, USA) fitted with a parallel-plate geometry (stainless steel, $40 \mathrm{~mm}$ diameter, $800 \mu \mathrm{m}$ gap). Shear rate range of 1-100 s-1 was used and shear rate, normal force, shear stress, apparent viscosity and torque data were measured during experiments. Stress sweep test was conducted to determine linear viscoelastic region. Frequency sweep test was performed at $0.6 \mathrm{~Pa}$ over a frequency range of $0.05-100 \mathrm{rad} / \mathrm{s}$ at $20^{\circ} \mathrm{C}$. The effect of temperature on viscosity of tarhana soups was also investigated between 5 and $60^{\circ} \mathrm{C}$.

\subsection{Sensory analysis}

Prepared tarhana soups were subjected to sensory evaluation. Ten people (five male and five female) who were familiar with the characteristics of tarhana were chosen. The soups were filled to porcelain bowl at $50^{\circ} \mathrm{C}$ and served to panelists under daylight room conditions. Panelists scored the tarhana soups regarding 
mouth feel, color, flavor, odour, sourness, consistency, taste and overall acceptability using five-point hedonic scale (1=extremely disliked, $5=$ =xtremely liked) (Erkan et al., 2006).

\subsection{Statistical analyses}

All of the analyses were performed three times. ANOVA was conducted with Tukey's test using SPSS (17.0) (SPSS Statistics 17.0, Armonk, NY, USA) to determine if the effect of kefir addition on the corresponding parameters of tarhana was significant or $\operatorname{not}(p<0.05)$.

\section{Results and discussion}

\subsection{Physicochemical properties of Tarhana samples}

Acidity and/or $\mathrm{pH}$ measurements can be used to monitor the fermentation activity of acidic fermentation (Hesseltine, 1979). During fermentation, changes in $\mathrm{pH}$, acidity degree, moisture, ash, protein and salt contents of tarhana dough were shown in Table 2. Formulations of tarhana had a sound influence on all the chemical parametres $(\mathrm{p}<0.05)$. During fermentation period, acidity degree, moisture and ash contents significantly changed $(\mathrm{p}<0.05)$. While acidity of the samples increased significantly $(\mathrm{p}<0.05)$ due to formation of organic acids with the fermentation of sugars by mostly $\mathrm{LAB}$, the $\mathrm{pH}$ value of the samples decreased. It was clear from Table 2 that addition of kefir increased the fermentation activity as increase in acidity values was observed compared to control tarhana sample prepared with yoghurt (A). This effect was observed more for sample B which can be possibly explained by the synergistic action of different bacteria population from yoghurt and kefir.
According to Mugula et al. (2003), higher level of increase in acidity and decrease in $\mathrm{pH}$ simultaneously were observed when a combined culture of lactobacilli and yeasts was used instead of single cultures. Acidity and $\mathrm{pH}$ change in this study were in agreement with the observations of previous works (Ekinci, 2005; Erbaş et al., 2006; Ibanoglu et al., 1995; Settanni et al., 2011).

Tarhana is known from its flavour and typical acidic taste. Therefore, taking into consideration of both sensory properties and antimicrobial activity, $\mathrm{pH}$ and acidity value of the final tarhana product is crucial (Hesseltine, 1979).

The moisture content of samples decreased continuously during fermentation $(\mathrm{p}<0.05)$. The decrease observed in moisture content as fermentation time progressed could be due to increased dry matter content as a result of microbial cell proliferation and evaporation of water at $30 \pm 1{ }^{\circ} \mathrm{C}$.

Ash content of fermented samples changed between $3.44-3.67 \%$. The ash content in all samples increased significantly $(\mathrm{p}<0.05)$ as fermentation period increased. Likewise, protein contents increased during the fermentation period. The rate of increase in ash and protein content was higher for $100 \%$ kefir added tarhana sample (C) than the others. Sample $C$ also showed a higher final ash and protein value $\mathrm{C}$ than sample A and $\mathrm{B}$. Fermentation improved the nutrient composition of fermented tarhana especially in sample $\mathrm{C}$ as there was an increase in acidity, protein and ash contents of tarhana at the end of fermentation.

The chemical compositions of dried tarhana samples are showed in Table 3. Amount of moisture in tarhana samples ranged between $10.37 \%(\mathrm{~A})$ and $12.14 \%$ (C). Drying method and type of ingredients were reported previously as the main cause for variation in moisture content of tarhana samples

Table 2. Chemical changes during tarhana fermentation.

\begin{tabular}{|c|c|c|c|c|c|c|c|}
\hline \multirow{2}{*}{$\begin{array}{l}\text { Tarhana } \\
\text { samples }\end{array}$} & \multirow[b]{2}{*}{$\begin{array}{l}\text { Time } \\
\text { (day) }\end{array}$} & \multicolumn{6}{|c|}{ Chemical parameteres } \\
\hline & & $\mathrm{pH}$ & $\begin{array}{l}\text { Acidity degree } \\
\text { (Lactic Acid) }\end{array}$ & $\begin{array}{c}\text { Moisture } \\
(\%)\end{array}$ & $\begin{array}{l}\text { Ash } \\
(\%)\end{array}$ & $\begin{array}{l}\text { Protein } \\
(\%)\end{array}$ & $\begin{array}{l}\text { Salt } \\
(\%)\end{array}$ \\
\hline \multirow[t]{3}{*}{ Dough A: } & 0 & $4.49 \pm 0.01 \mathrm{Ca}$ & $8.44 \pm 0.01 \mathrm{Be}$ & $43.15 \pm 0.03 \mathrm{Ba}$ & $2.65 \pm 0.01 \mathrm{Bd}$ & $12.14 \pm 0.05 \mathrm{Ac}$ & $4.00 \pm .02 \mathrm{Cc}$ \\
\hline & 3 & $4.41 \pm 0.01 \mathrm{Cb}$ & $8.78 \pm 0.03 \mathrm{Bc}$ & $40.31 \pm 0.04 \mathrm{Cc}$ & $3.27 \pm 0.05 \mathrm{Bb}$ & $13.58 \pm 0.09 \mathrm{Ab}$ & $4.10 \pm 0.03 \mathrm{Cab}$ \\
\hline & 5 & $4.27 \pm 0.01 \mathrm{Cc}$ & $9.04 \pm 0.01 \mathrm{Bb}$ & $40.0 \pm 0.2 \mathrm{Bd}$ & $3.34 \pm 0.02 \mathrm{Bb}$ & $13.95 \pm 0.07 \mathrm{Aa}$ & $4.13 \pm 0.08 \mathrm{Ca}$ \\
\hline \multirow[t]{5}{*}{ Dough B: } & 0 & $4.68 \pm 0.01 \mathrm{Ba}$ & $6.18 \pm 0.02 \mathrm{Ce}$ & $43.37 \pm 0.04 \mathrm{Be}$ & $2.75 \pm 0.02 \mathrm{Ae}$ & $11.37 \pm 0.07 \mathrm{Bd}$ & $4.59 \pm 0.02 \mathrm{Bc}$ \\
\hline & 1 & $4.68 \pm 0.02 \mathrm{Ba}$ & $7.02 \pm 0.02 \mathrm{Cd}$ & $43.1 \pm 0.1 \mathrm{Bd}$ & $2.91 \pm 0.02 \mathrm{Ad}$ & $11.9 \pm 0.1 \mathrm{Cc}$ & $4.62 \pm 0.02 \mathrm{Bbc}$ \\
\hline & 3 & $4.67 \pm 0.00 \mathrm{Ba}$ & $7.58 \pm 0.04 \mathrm{Cc}$ & $40.99 \pm 0.06 \mathrm{Bc}$ & $3.37 \pm 0.05 \mathrm{ABc}$ & $12.5 \pm 0.3 \mathrm{Bb}$ & $4.67 \pm 0.05 \mathrm{Babc}$ \\
\hline & 5 & $4.55 \pm 0.02 \mathrm{Bb}$ & $8.14 \pm 0.05 \mathrm{Cb}$ & $40.31 \pm 0.08 \mathrm{Bb}$ & $3.48 \pm 0.04 \mathrm{Ab}$ & $13.7 \pm 0.1 \mathrm{Ba}$ & $4.74 \pm 0.06 \mathrm{Bab}$ \\
\hline & 7 & $4.53 \pm 0.01 \mathrm{Bb}$ & $8.45 \pm 0.02 \mathrm{Ca}$ & $39.98 \pm 0.05 \mathrm{Aa}$ & $3.63 \pm 0.04 \mathrm{Aa}$ & $13.9 \pm 0.2 \mathrm{Ba}$ & $4.80 \pm 0.07 \mathrm{Ba}$ \\
\hline \multirow{2}{*}{ Dough C: } & 5 & $4.71 \pm 0.01 \mathrm{Ab}$ & $9.15 \pm 0.02 \mathrm{Ab}$ & $40.86 \pm 0.08 \mathrm{Ab}$ & $3.58 \pm 0.05 \mathrm{Aab}$ & $14.15 \pm 0.08 \mathrm{Aa}$ & $5.05 \pm 0.07 \mathrm{Aab}$ \\
\hline & 7 & $4.62 \pm 0.01 \mathrm{Ac}$ & $9.34 \pm 0.06 \mathrm{Aa}$ & $39.5 \pm 0.1 \mathrm{Ba}$ & $3.67 \pm 0.02 \mathrm{Aa}$ & $14.4 \pm 0.1 \mathrm{Aa}$ & $5.08 \pm 0.07 \mathrm{Aa}$ \\
\hline
\end{tabular}

Dough A: Control tarhana sample (prepared with yoghurt); Dough B: Tarhana sample with 50\% kefir (based on the yoghurt used); Dough C: tarhana sample with 100\% kefir (based on the yoghurt used). Mean value \pm standard deviation, $n=3$; Different letters in capital (A and B) show the significant differences among samples $(p<0.05)$; Different letters in lowercase (a, b, c, d and e) show the significant differences among days $(p<0.05)$. 
(Temiz \& Pirkul, 1991). The values of the dried products were compatible with the values on the last day of fermentation and the highest ash, salt, protein and total phenolic amounts were obtained with $100 \%$ kefir addition due to richer chemical composition of kefir than yoghurt. The tarhana sample without yoghurt $(\mathrm{C})$ had a higher acidity degree and lower $\mathrm{pH}$ level than the other two dried samples ( $\mathrm{p}<0.05)$. This can be due to acid formation of LAB which were found in kefir and took role in fermentation process. $\mathrm{pH} 4-5$ was reported as a typical range for tarhana-like products (Hesseltine, 1979).

Ash and total phenolic content of the tarhana sample prepared with $100 \%$ kefir was significantly higher $(\mathrm{p}<0.05)$ than other samples, while control sample had the lowest values. The reason of the high phenolic content can be explained by the formation of polymeric phenolics during fermentation by the microorganisms in Kefir culture. Tarhana was found as a good source of protein since the amounts of crude protein were determined in all dried tarhana samples between $14.56 \%$ and $16.45 \%$. Crude fat contents of samples were not changed significantly $(\mathrm{p}>0.05)$.
These results were generally in agreement with similar works conducted with tarhana (Bozkurt \& Gürbüz, 2008; Ibanoglu et al., 1995; Tamer et al., 2006).

\subsection{Microbiological analysis}

The microbiological counts of the tarhana samples during fermentation are presented in Table 4 . All tarhana samples were characterized by approximately same microbial concentrations at the beginning of fermentation. Coliforms were detected only at time 0 in $\mathrm{A}$ and $\mathrm{C}$ samples, at time 0 and $1^{\text {st }}$ day of fermentation in B sample. After $1^{\text {st }}$ day of fermentation, coliforms were not detected during the whole process.

The counts of TMAB (Total Mesophilic Aerobic Bacteria) increased significantly due to low acid content and high $\mathrm{pH}$ value of the dough during the first day of fermentation $(\mathrm{p}<0.05)$. However, increase in the acid content probably caused decrease in the formation of compounds such as diacetyl, carbon dioxide, hydrogen peroxide, ethanol and bacteriosins in the following days. As similar to previous studies, TMAB population also increased at first then decreased because of acid formation.

Table 3. Characteristics of dried and ground tarhana samples on dry basis.

\begin{tabular}{|c|c|c|c|c|c|c|c|c|}
\hline $\begin{array}{l}\text { Tarhana } \\
\text { Samples }\end{array}$ & $\begin{array}{c}\text { Moisture } \\
(\%)\end{array}$ & $\begin{array}{c}\text { Crude fat } \\
(\%)\end{array}$ & $\begin{array}{l}\text { Crude protein } \\
(\%)\end{array}$ & $\begin{array}{l}\text { Acidity degree } \\
\text { (Lactic Acid) }\end{array}$ & $\mathrm{pH}$ & $\begin{array}{l}\text { Salt } \\
(\%)\end{array}$ & $\begin{array}{l}\text { Ash } \\
(\%)\end{array}$ & $\begin{array}{c}\text { Total phenolic } \\
\text { compounds } \\
(\mathrm{mg} / \mathrm{kg})\end{array}$ \\
\hline A & $10.37 \pm 0.03 a$ & $2.0 \pm 0.1 \mathrm{a}$ & $15.96 \pm 0.06 b$ & $15 \pm 0.02 b$ & $4.15 \pm 0.01 \mathrm{~b}$ & $4.11 \pm 0.04 b$ & $3.69 \pm 0.04 \mathrm{~b}$ & $2.15 \pm 0.01 c$ \\
\hline $\mathrm{C}$ & $12.14 \pm 0.04 c$ & $2.0 \pm 0.2 \mathrm{a}$ & $16.45 \pm 0.07 a$ & $18 \pm 0.07 a$ & $3.40 \pm 0.01 \mathrm{c}$ & $3.62 \pm 0.06 c$ & $4.36 \pm 0.06 \mathrm{a}$ & $2.87 \pm 0.01 \mathrm{a}$ \\
\hline
\end{tabular}

A: Control tarhana sample (prepared with yoghurt); B: Tarhana sample with 50\% kefir (based on the yoghurt used); C: tarhana sample with 100\% kefir (based on the yoghurt used) Mean value \pm standard deviation, $n=3$; Different letters in lowercase (a, b and c) show the significant differences among samples $(p<0.05)$.

Table 4. Microbial changes during tarhana fermentation $\left(\log _{10} \mathrm{cfu} / \mathrm{g}\right)$.

\begin{tabular}{|c|c|c|c|c|c|c|}
\hline \multirow{2}{*}{$\begin{array}{l}\text { Tarhana } \\
\text { Samples }\end{array}$} & \multirow{2}{*}{ Microorganisms } & \multicolumn{5}{|c|}{ Days } \\
\hline & & 0 & 1 & 3 & 5 & 7 \\
\hline \multirow[t]{5}{*}{ A } & TMAB & $7.30 \pm 0.01(\mathrm{~B}, \mathrm{c})$ & $8.0 \pm 0.20(\mathrm{~A}, \mathrm{a})$ & $7.99 \pm 0.02(\mathrm{~A}, \mathrm{a})$ & $7.81 \pm 0.01(\mathrm{~A}, \mathrm{~b})$ & $7.9 \pm 0.1(\mathrm{~A}, \mathrm{ab})$ \\
\hline & Yeast and Mould & $7.45 \pm 0.02(\mathrm{~A}, \mathrm{~d})$ & $8.4 \pm 0.3(\mathrm{~A}, \mathrm{a})$ & $7.9 \pm 0.2(\mathrm{~A}, \mathrm{~b})$ & $7.7 \pm 0.1(\mathrm{~A}, \mathrm{c})$ & $7.76 \pm 0.02(\mathrm{~A}, \mathrm{c})$ \\
\hline & Coliform & $2.4 \pm 0.4(\mathrm{~A})$ & $<2.0$ & $<2.0$ & $<2.0$ & $<2.0$ \\
\hline & S. aureus & $2.6 \pm 0.2(\mathrm{~B})$ & $<2.0$ & $<2.0$ & $<2.0$ & $<2.0$ \\
\hline & LAB (MRS) & $8.40 \pm 0.01(\mathrm{~B}, \mathrm{a})$ & $8.00 \pm 0.08(\mathrm{~A}, \mathrm{~b})$ & $7.86 \pm 0.02(\mathrm{~A}, \mathrm{c})$ & $7.86 \pm 0.04(\mathrm{~A}, \mathrm{c})$ & $7.89 \pm 0.02(\mathrm{~A}, \mathrm{c})$ \\
\hline \multirow{5}{*}{ B } & Yeast and Mould & $7.32 \pm 0.03(B, c)$ & $7.85 \pm 0.04(\mathrm{C}, \mathrm{a})$ & $7.7 \pm 0.1(\mathrm{C}, \mathrm{b})$ & $7.67 \pm 0.03(\mathrm{~A}, \mathrm{~b})$ & $7.7 \pm 0.2(\mathrm{~A}, \mathrm{~b})$ \\
\hline & Coliform & $2.5 \pm 0.2(\mathrm{~A})$ & $2.0 \pm 0.3$ & $<2.0$ & $<2.0$ & $<2.0$ \\
\hline & S. aureus & $4.3 \pm 0.2(\mathrm{~A})$ & $1.98 \pm 0.08$ & $1.69 \pm 0.05$ & $<2.0$ & $<2.0$ \\
\hline & LAB (MRS) & $8.30 \pm 0.01(\mathrm{C}, \mathrm{a})$ & $7.95 \pm 0.03(\mathrm{~A}, \mathrm{~b})$ & $7.8 \pm 0.1(\mathrm{~B}, \mathrm{c})$ & $7.8 \pm 0.1(\mathrm{~B}, \mathrm{c})$ & $7.94 \pm 0.02(\mathrm{~A}, \mathrm{~b})$ \\
\hline & M 17 & $8.41 \pm 0.02(\mathrm{~B}, \mathrm{a})$ & $7.93 \pm 0.02(B, b)$ & $7.8 \pm 0.3(\mathrm{C}, \mathrm{c})$ & $7.7 \pm 0.2(\mathrm{~B}, \mathrm{~d})$ & $7.77 \pm 0.03(\mathrm{~B}, \mathrm{~cd})$ \\
\hline \multirow{3}{*}{$\mathrm{C}$} & S. aureus & $2.5 \pm 0.3(\mathrm{~B})$ & $1.98 \pm 0.08$ & $1.65 \pm 0.04$ & $<2.0$ & $<2.0$ \\
\hline & LAB (MRS) & $8.5 \pm 0.1(\mathrm{~A}, \mathrm{a})$ & $8.00 \pm 0.05(\mathrm{~A}, \mathrm{~b})$ & $7.85 \pm 0.04(\mathrm{~A}, \mathrm{~d})$ & $7.73 \pm 0.02(\mathrm{~B}, \mathrm{e})$ & $7.95 \pm 0.03(\mathrm{~A}, \mathrm{c})$ \\
\hline & M 17 & $8.51 \pm 0.04(\mathrm{~A}, \mathrm{a})$ & $8.0 \pm 0.1(\mathrm{~A}, \mathrm{~b})$ & $7.92 \pm 0.02(\mathrm{~B}, \mathrm{c})$ & $7.73 \pm 0.08(\mathrm{~B}, \mathrm{e})$ & $7.81 \pm 0.02(\mathrm{~B}, \mathrm{~d})$ \\
\hline
\end{tabular}

A: Control tarhana sample (prepared with yoghurt); B: Tarhana sample with $50 \%$ kefir (based on the yoghurt used); C: tarhana sample with $100 \%$ kefir (based on the yoghurt used). Mean value \pm standard deviation, $n=3$; Different letters in capital (A, B and C) show the significant differences among samples $(p<0.05)$; Different letters in lowercase (a, b, c, d and e) show the significant differences among days $(p<0.05)$; TMAB: Total Mesophilic Aerobic Bacteria, LAB: Lactic Acid Bacteria. 
(Erbaş et al., 2005; Ibanoglu et al., 1999a). Yeast and mold counts showed a comparable result with the highest count values at day 1 . The increase in yeast and mold number at the first day of fermentation indicated the involvement of yeast fermentation in the tarhana fermentation. $\mathrm{CO}_{2}$ production because of leavening of the batter was observed during the first day of fermentation as the free sugars available in the dough was readily fermented by yeasts. The initial high number of yeast and mold was not surprising, since similar concentrations of yeast and LAB were generally observed for this product (Sengun et al., 2009).

The tarhana sample $\mathrm{C}$ had a higher lactic acid bacteria and TMAB population than the other two samples at the beginning of the fermentation $(\mathrm{p}<0.05)$ (Table 4$)$. This was expected, since kefir have more bacteria population. The counts of LAB decreased continuously during the 5 day of fermentation. The final rod $\mathrm{LAB}$ of dough $\mathrm{C}$ and $\mathrm{B}$ were similar and higher than in standard tarhana (A).

Erbaş et al. (2005), Settanni et al. (2011) and Ibanoglu et al. (1999b) reported that LAB counts increased in the first days of fermentation and then decreased. They did never detected coliforms during the whole process. Daglioglu et al. (2002) reported the highest $\mathrm{LAB}$ counts on the second day of fermentation and observed a stable or decreasing trend on the following days. These slight difference on microbiological results demonstrated that fermentation temperature and time as well as the composition caused significant change in the number of microorganisms.

\subsection{Sensorial analysis}

Table 5 showed sensorial properties of tarhana samples. Difference in composition of tarhana samples had significant effect ( $p<0.05$ ) on odour, color, taste and flavour. Tarhana soup with kefir (C) had high scores in terms of mouth feel, odour and consistency attributes (Table 5). Whereas, tarhana soup with yoghurt (A) had the highest scores in terms of color and taste. This result might be caused by the habit of taste and color of classical tarhana. Flavour, sourness and overall acceptability values of A were generally comparable to that of sample C.

On the sensory properties, panelists gave lower scores for the sample with $50 \%$ yoghurt/kefir in the formulation.

Table 5. Results of sensory analysis of Tarhana soups.

\begin{tabular}{cccc}
\hline Sensory & \multicolumn{3}{c}{ Tarhana Samples } \\
\cline { 2 - 4 } properties & $\mathrm{A}$ & $\mathrm{B}$ & $\mathrm{C}$ \\
\hline Mouth feel & $3.7 \pm 0.1 \mathrm{~b}$ & $3.6 \pm 0.2 \mathrm{~b}$ & $4.2 \pm 0.1 \mathrm{a}$ \\
Odour & $4.0 \pm 0.01 \mathrm{~b}$ & $3.00 \pm 0.03 \mathrm{c}$ & $4.40 \pm 0.02 \mathrm{a}$ \\
Color & $4.50 \pm 0.03 \mathrm{a}$ & $2.7 \pm 0.1 \mathrm{c}$ & $4.00 \pm 0.02 \mathrm{~b}$ \\
Taste & $4.30 \pm 0.03 \mathrm{a}$ & $3.40 \pm 0.07 \mathrm{c}$ & $4.00 \pm 0.03 \mathrm{~b}$ \\
Flavour & $4.20 \pm 0.07 \mathrm{a}$ & $3.40 \pm 0.03 \mathrm{~b}$ & $4.2 \pm 0.2 \mathrm{a}$ \\
Consistency & $3.8 \pm 0.1 \mathrm{a}$ & $3.7 \pm 0.3 \mathrm{a}$ & $4.1 \pm 0.2 \mathrm{a}$ \\
Sourness & $3.7 \pm 0.4 \mathrm{a}$ & $3.6 \pm 0.2 \mathrm{a}$ & $3.7 \pm 0.3 \mathrm{a}$ \\
Overall & $4.1 \pm 0.1 \mathrm{a}$ & $3.30 \pm 0.07 \mathrm{~b}$ & $4.10 \pm 0.05 \mathrm{a}$ \\
acceptability & & & \\
\hline A: Control tarhana sample (prepared with yoghurt); B: Tarhana sample with $50 \%$ kefir \\
(based on the yoghurt used); C: tarhana sample with 100\% kefir (based on the yoghurt \\
used); Mean value \pm standard deviation, $n=3$; Different letters in lowercase (a, b and c) \\
show the significant differences among samples $(p<0.05$ ).
\end{tabular}

The overall sensorial results demonstrated that use of kefir instead of yoghurt in tarhana production resulted in acceptable soup properties concerning overall preference of the panelists.

\subsection{Rheological analysis}

The rheological properties of soups are important as they primarily affect the sensory quality, and hence consumer preference. Therefore, it is important to evaluate rheological results according to sensorial results. Interestingly, sensorial results showed that consistency and mouth feel of the sample made with $100 \%$ kefir was the highest. However, dynamic values, storage modulus $\left(G^{\prime}\right)$ and loss modulus $\left(G^{\prime}\right)$ and viscosity of that kefir sample was not higher than Tarhana sample made with $100 \%$ yoghurt (Figure 1a and 2 ). This demonstrated that viscosity or dynamic rheological data fell short to correlate with sensory data for tarhana samples. The results were in agreement with
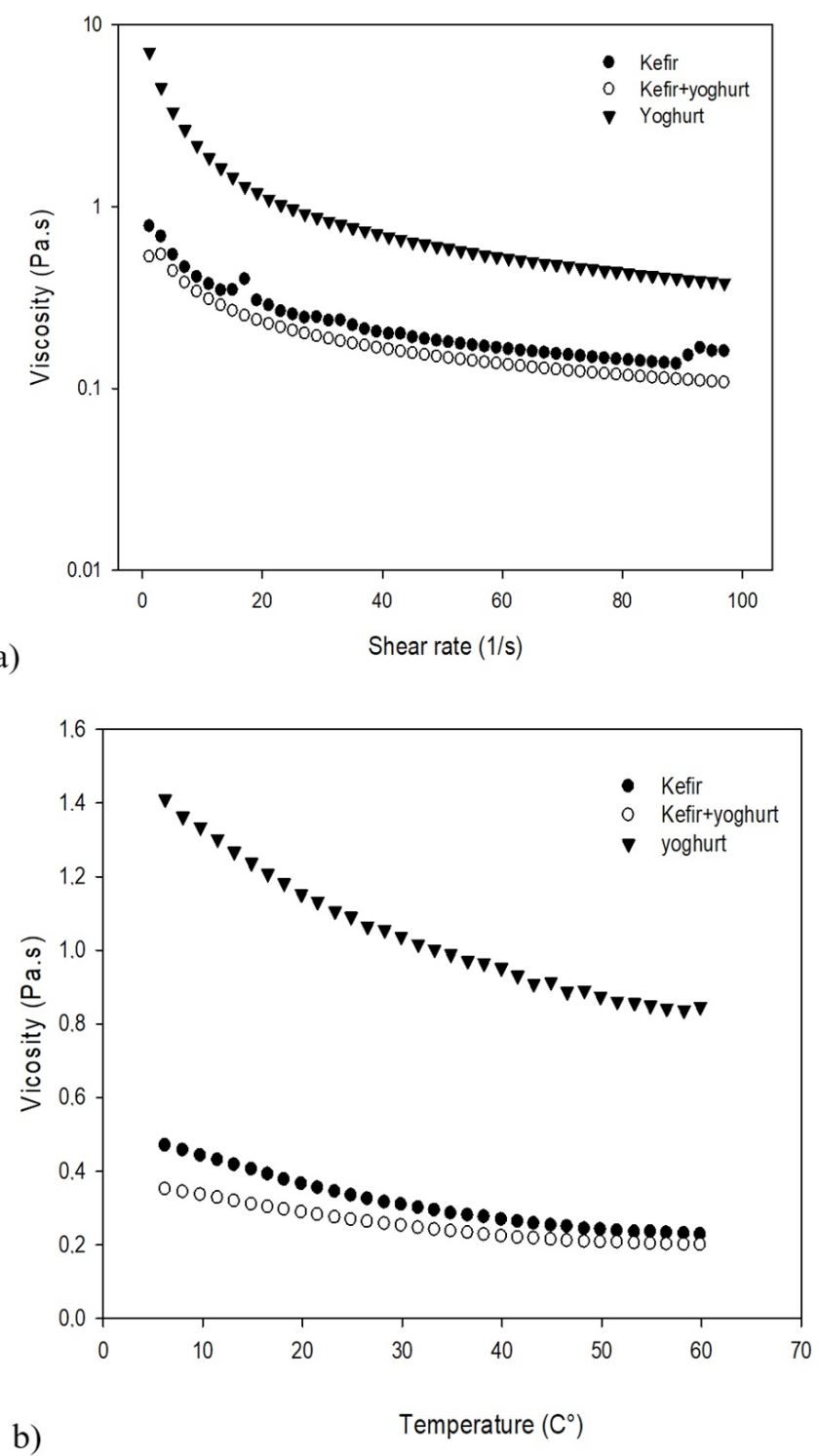

Figure 1. Viscosity change of Tarhana samples as a function of (a) shear rate $(1 / \mathrm{s})$ and $(\mathrm{b})$ temperature $\left(\mathrm{C}^{\circ}\right)$. 


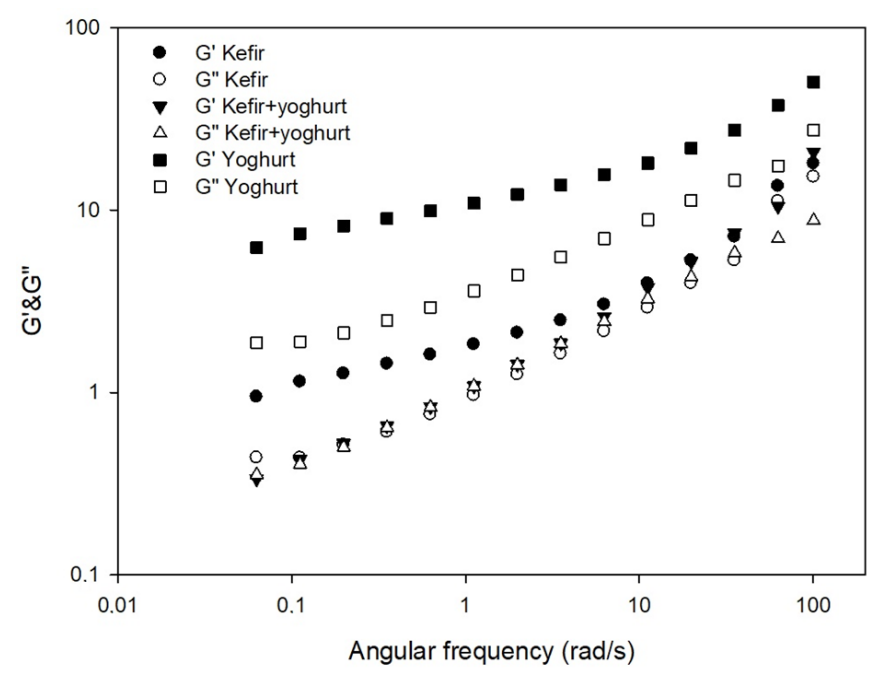

Figure 2. Storage (G') and loss modulus (G') change of Tarhana samples as a function of angular frequency $(\mathrm{rad} / \mathrm{s})$.

de Wijk et al. (2006). For starch included samples, they found that viscosity at $50 \mathrm{~s}^{-1}$ did not correlate with complex sensory sensations. Tarhana samples showed pseudoplastic behavior as when shear rate increased, viscosity decreased (Figure 1a). Similarly, Yilmaz et al. (2010) found the same behavior for tarhana samples. All the samples showed decrease in viscosity by increase in temperature (Figure 1b) since this was general behavior for soups. Dynamic rheological behavior of tarhana samples demonstrated that G' was higher than G" for tarhana samples made with $100 \%$ kefir and yoghurt indicating their elastic behavior which was desired property for soups (Figure 2). Therefore, tarhana sample made with 50\% yoghurt and 50\% kefir cannot be accepted rheologically which was in agreement with our sensory data in Table 5 for overall acceptance. The lower viscosity and high G" value of tarhana soup sample made with $50 \%$ yoghurt and $50 \%$ kefir could be attributed to higher amont of starch hydrolyzed since starch was the main hydrocolloid gave rise to viscosity development in soups. Different microorganisms from yoghurt and kefir increased the hydrolysis level of starch and affected synergisticly on starch degradation.

\section{Conclusion}

Yoghurt is undoubtedly best known fermented milk product, consumed in the world and used in traditional tarhana production due to having LAB. However, kefir represents another important fermented milk product offering a good alternative in tarhana fermentation.

Addition of kefir increased the fermentation activity compared to control tarhana sample.

The highest acidity degree, protein, ash, and total phenolic contents were detected in tarhana sample prepared with $100 \%$ kefir. The soup formulated with $100 \%$ kefir instead of yoghurt was the most preferred tarhana soup in terms of most of the sensory properties. Lower viscosity and fluid like behavior was observed for tarhana soup made with 50\% yoghurt and kefir indicating not acceptable rheological behavior and sensorial preference. However, kefir included sample showed better rheological behavior which could influence consumer preference positively. The use of kefir which is known to have significant benefits in human nutrition, in the production of traditional tarhana will allow diversification of historical and cultural products in order to make consumption more widespread.

\section{Acknowledgements}

The authors gratefully acknowledge the Namik Kemal University Research Fund for providing funding for this work (NKUBAP.03.GA.16.054).

\section{References}

American Association of Cereal Chemists - AACC. (1990). Approved Methods of the AACC (8th ed.). Arlington: The Association.

Anonymous (1981). TSE tarhana standard. Official methods of analysis. Bakanlıklar: The Institute of Turkish Standard.

Bilgiçli, N., Elgün, A., Herken, E. N., Türker, S., Ertaş, N., \& İbanog `lu, S. (2006). Effect of wheat germ/bran addition on the chemical, nutritional and sensory quality of tarhana, a fermented wheat flouryoghurt product. Journal of Food Engineering, 77(3), 680-686. http:// dx.doi.org/10.1016/j.jfoodeng.2005.07.030.

Bozkurt, O., \& Gürbüz, O. (2008). Comparison of lactic acid contents between dried and frozen tarhana. Food Chemistry, 108(1), 198-204. http://dx.doi.org/10.1016/j.foodchem.2007.10.063.

Daglioglu, O. (2000). Tarhana as a traditional Turkish fermented cereal food. Its recipe, production and composition. Die Nahrung, 44(2), 85-88. http://dx.doi.org/10.1002/(SICI)1521-3803(20000301)44:2<85::AIDFOOD85>3.0.CO;2-H. PMid:10795573.

Daglioglu, O., Arici, M., Konyali, M., \& Gumus, T. (2002). Effects of tarhana fermentation and drying methods on the fate of Escherichia coli 0157:H7 and Staphylococcus aureus. European Food Research and Technology, 215(6), 515-519. http://dx.doi.org/10.1007/s00217002-0584-0.

De Wijk, R. A., Prinz, J. F., \& Janssen, A. M. (2006). Explaining perceived oral texture of starch-based custard desserts from standard and novel instrumental tests. Food Hydrocolloids, 20(1), 24-34. http:// dx.doi.org/10.1016/j.foodhyd.2005.02.008.

Ekinci, R. (2005). The effect of fermentation and drying on the watersoluble vitamin content of tarhana, a traditional Turkish cereal food. Food Chemistry, 90(1-2), 127-132. http://dx.doi.org/10.1016/j. foodchem.2004.03.036.

Erbaş, M., Certel, M., \& Kemal Uslu, M. (2005). Microbiological and chemical properties of Tarhana during fermentation and storage as wet - Sensorial properties of Tarhana soup. Lebensmittel-Wissenschaft + Technologie, 38(4), 409-416. http://dx.doi.org/10.1016/j.lwt.2004.06.009.

Erbaş, M., Kemal Uslu, M., Ozgun Erbaş, M., \& Certel, M. (2006). Effects of fermentation and storage on the organic and fatty acid contents of tarhana, a Turkish fermented cereal food. Journal of Food Composition and Analysis, 19(4), 294-301. http://dx.doi. org/10.1016/j.jfca.2004.12.002.

Erkan, H., Çelik, S., Bilgi, B., \& Köksel, H. (2006). A new approach for the utilization of barley in food products: Barley tarhana. Food Chemistry, 97(1), 12-18. http://dx.doi.org/10.1016/j.foodchem.2005.03.018.

Hesseltine, C. W. (1979). Some important fermented foods of Mid-Asia, the Middle East, and Africa. Journal of the American Oil Chemists' 
Society, 56(3), 367-374. http://dx.doi.org/10.1007/BF02671501. PMid:536552.

Ibanoglu, S., Ainsworth, P., Wilson, G., \& Hayes, G. D. (1995). The effect of fermentation conditions on the nutrients and acceptability of tarhana. Food Chemistry, 53(2), 143-147. http://dx.doi.org/10.1016/03088146(95)90779-7.

Ibanoglu, Ş., Ibanoglu, E., \& Ainsworth, P. (1999a). Effect of different ingredients on the fermentation activity in tarhana. Food Chemistry, 64(1), 103-106. http://dx.doi.org/10.1016/S0308-8146(98)00071-5.

Ibanoglu, S., Kaya, S., \& Kaya, A. (1999b). Evaluation of sorption properties of Turkish tarhana powder. Nahrung - Food, 43(2), 122-125.

Kirk, R. S., \& Sawyer, R. (1991). Pearson's composition and analysis of foods (9th ed.). Harlow: Longman Scientific \& Technical.

Koca, A. F., Yazici, F., \& Anil, M. (2002). Utilization of soy yoghurt in tarhana production. European Food Research and Technology, 215(4), 293-297. http://dx.doi.org/10.1007/s00217-002-0568-0.

Kumral, A. (2015). Nutritional, chemical and microbiological changes during fermentation of tarhana formulated with different flours. Chemistry Central Journal, 9(16), 1-9. PMid:25852769.

Libudzsis, Z., \& Piatkiewicz, A. (1990). Kefir production in Poland. Dairy Industries International, 55, 31-33.

Meignen, B., Onno, B., Gelinas, P., Infantes, M., Guilois, S., \& Cahagnier, B. (2001). Optimization of sourdough fermentation with Lactobacillus brevis and baker's yeast. Food Microbiology, 18(3), 239-245. http:// dx.doi.org/10.1006/fmic.2000.0395.

Mensah, P. (1997). Fermentation - the key to food safety assurance in Africa? Food Control, 8(5-6), 271-278. http://dx.doi.org/10.1016/ S0956-7135(97)00020-0.

Messens, W., \& De Vuyst, L. (2002). Inhibitory substances produced by Lactobacilli isolated from sourdoughs - A review. International Journal of Food Microbiology, 72(1-2), 31-43. http://dx.doi.org/10.1016/ S0168-1605(01)00611-0. PMid:11843411.

Mugula, J. K., Narvhus, J. A., \& Sorhaug, T. (2003). Use of starter cultures of lactic acid bacteria and yeasts in the preparation of togwa, a Tanzanian fermented food. International Journal of Food Microbiology, 83(3), 307-318. http://dx.doi.org/10.1016/S01681605(02)00386-0. PMid:12745235.

Sengun, I. Y., Nielsen, D. S., Karapinar, M., \& Jakobsen, M. (2009). Identification of lactic acid bacteria isolated from Tarhana, a traditional
Turkish fermented food. International Journal of Food Microbiology, 135(2), 105-111. http://dx.doi.org/10.1016/j.ijfoodmicro.2009.07.033. PMid:19703719.

Settanni, L., Tanguler, H., Moschetti, G., Reale, S., Gargano, V., \& Erten, H. (2011). Evolution of fermenting microbiota in tarhana produced under controlled technological conditions. Food Microbiology, 28(7), 1367-1373. http://dx.doi.org/10.1016/j.fm.2011.06.008. PMid:21839387.

Simova, E., Beshkova, D., Angelov, A., Hristozova, T., Frengova, G., \& Spasov, Z. (2002). Lactic acid bacteria and yeasts in kefir grains and kefir made from them. Journal of Industrial Microbiology \& Biotechnology, 28(1), 1-6. http://dx.doi.org/10.1038/sj/jim/7000186. PMid:11938463.

Škerget, M., Kotnik, P., Hadolin, M., Hraš, A. R., Simonič, M., \& Knez, Ž. (2005). Phenols, proanthocyanidins, flavones and flavonols in some plant materials and their antioxidant activities. Food Chemistry, 89(2), 191-198. http://dx.doi.org/10.1016/j.foodchem.2004.02.025.

Tamer, C. E., Kumral, A., Aşan, M., \& Şahin, İ. (2006). Having different formulations. Journal of Food Processing and Preservation, 31(2007), 116-126.

Tarakçi, Z., Dogan, I. S., \& Koca, A. F. (2004). A traditional fermented Turkish soup, tarhana, formulated with corn flour and whey. International Journal of Food Science \& Technology, 39(4), 455-458. http://dx.doi.org/10.1111/j.1365-2621.2004.00803.x.

Temiz, A., \& Pirkul, T. (1991). Farklı bileşimlerde üretilen tarhanaların kimyasal ve duyusal özellikleri (The chemical and sensorial properties of tarhana in different compositions). Gida, 16(1), 7-13.

Toufeili, I., Melki, C., Shadarevian, S., \& Robinson, R. K. (1998). Some nutritional and sensory properties of bulgur and whole wheatmeal kishk (a fermented milk-wheat mixture). Food Quality and Preference, 10(1), 9-15. http://dx.doi.org/10.1016/S0950-3293(98)00016-0.

Türker, S., \& Elgün, A. (1995). Nutritional value of naturally or yeast fermented (Sacharomyces cerevisiae) tarhana supplemented with sound, cooked and germination dry legumes. Journal of Agricultural Faculty of Selcuk University, 8, 32-45.

Yilmaz, M. T., Sert, D., \& Demir, M. K. (2010). Rheological properties of tarhana soup enriched with whey concentrate as a function of concentration and temperature. Journal of Texture Studies, 41(6), 863-879. http://dx.doi.org/10.1111/j.1745-4603.2010.00259.x. 